\title{
Effect of plant spacing on growth and yield of winged bean ${ }^{1,2}$
}

\begin{abstract}
C.T. Lee
ABSTRACT

The effect of plant spacing on growth and yield of winged bean (Psophocarpus tetragonolobus (L.)D.C.) cultivar Chimbu was evaluated at Guam Agricultural Experiment Station. Plant spacings included 12.5, 25.0, 50.0 and $75.0 \mathrm{~cm}$ within-row at the same between-row spacing of $1.22 \mathrm{~m}$ (equivalent to 13,333, 20,000, 40,000 and 80,000 plants/ha, respectively). Days to first flower in closest spacing $(12.5 \mathrm{~cm})$ was significantly delayed 8 days longer than that from widest spacing $(75 \mathrm{~cm})$. Wider spacings of 50 and $75 \mathrm{~cm}$ produced higher numbers of basal branches (3.6 and 3.8 , respectively) and green pods per plant (65.3 and 83.3, respectively) than closer spacings of 12.5 and $25 \mathrm{~cm}$. For yields both of green pod and dry seed the optimum spacings were plant spacings of 50 and $75 \mathrm{~cm}$. The result of higher yields indicated that cultivar Chimbu compensated for wider spacings by producing higher numbers of basal branches and green pods and larger green pods than at closer spacings.
\end{abstract}

\section{INTRODUCTION}

Winged bean has been identified as a crop for potentially easing the protein mulnutrition throughout the humid tropics. ${ }^{4}$ Although Chimbu was identified as one of the cultivars with potential for growing in Guam ${ }^{5}$, there is little documented information on optimum cultural requirements. Previous studies with other cultivars of winged bean and other legume crops under tropical conditions have pointed to the importance of increased plant populations of higher yields ${ }^{6,7}$. This study was conducted to determine influence of plant spacings on growth and yield of a selected winged bean cultivar.

'Manuseript submitted to Editorial Board 15 July 1987.

2This study was conducted under USDA Section 406 - Tropical and Sub-tropical Agricultural Research Grant. The author thanks Dr. C. T. Tseng for assistance in analysis of data.

${ }^{3}$ Professor of Horticulture.

${ }^{4}$ National Academy of Science, 1981. The Winged Bean; a high-protein crop for the tropics. 2nd ed, NAS, Washington, C. D. p. 45.

${ }^{6}$ Lee, C. T., 1983. Evaluation of production potential of winged beans (Psophocarpus tetragonolobus) under long photoperiod condition of Guam. Paper presented in the 75th Annu. Meet. Am. Soc. Agron., Agron. Abst. 108-09.

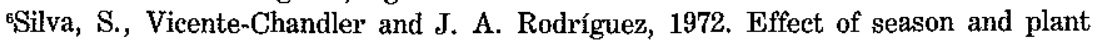
spacing on yields of intensively managed soybeans under tropical conditions J. Agric. Univ. P. R. 54 (4):365-69.

TThompson, A. E. and S. K. Haryono, 1980. Winged Bean: Unexploited tropical food crop. HortScience 15: 233-38. 


\section{MATERIALS AND METHODS}

An experiment was conducted at Guam Agricultural Experiment Station. The soils are fine, Alfisol alkaline, oxidic, isohyperthermic, Oxic Paleustalfs, with $\mathrm{pH} 7.6$, organic matter $3.8 \%$, cation exchange capacity $14 \mathrm{meq} / 100 \mathrm{~g}$ of soil, available $\mathrm{P} 14 \mathrm{p} / \mathrm{m}$, and exchangeable cations in $\mathrm{p} / \mathrm{m}$; $\mathrm{K}-88, \mathrm{Ca}-6,000$ and $\mathrm{Mg}-150$.

Four treatments were set up with plants spaced at 12.5, 25, 50 and $75 \mathrm{~cm}$ within row and $1.22 \mathrm{~m}$ between rows. These spacings are roughly equivalent to densities of $13,333,20,000,40,000$ and 80,000 plants/ha. The treatments were replicated 3 times in a randomized complete block design with cultivar Chimbu. Each experimental plot was 4 rows $4.57 \mathrm{~m}$ long.

Before being planted the winged bean seeds were immersed in a concentrated sulfuric acid (sp. gr. 1.84) at $25^{\circ} \mathrm{C}$ for $5 \mathrm{~min}$ followed by a 10-minute rinse under running tap water. The seeds were sown directly in the field on 3 September 1984. The whole field received a blanket application of $387 \mathrm{~kg} / \mathrm{ha}$ of a 10-20-20 fertilizer before planting. Sidedressing with the same fertilizer at the same rate was done 4 weeks after planting. Preventive spraying was done once weekly to reduce possible insect damage. Kelthane and Malathion 50 were used. A rotary tiller and garden hoe were used to control weeds. Sprinklers were used as needed for irrigation. The plants were supported with a trellis constructed of leucaena (Leucaena leucocephala (Lam.) de Wit) stakes and plastic net.

Data were taken on days to first flower, number of basal branches and green pods per plant, weight of green pods, and yields of green pods and dry seed.

\section{RESULTS AND DISCUSSION}

No major disease was evident during the experimental period. The major pests were aphids and whiteflies, which sucked the young leaves. Effective control of these insects was achieved with the application of Malathion 50.

Plots with closest spacing produced a dense, heavy canopy. The main difficulty was providing trellises strong enough to support the mass of plant material, especially during a storm or high winds.

\section{Days to first flower}

Appearance of first flower ranged from 63 to 71 days (table 1). First flowering in closest spacing $(12.5 \mathrm{~cm})$ was significantly delayed, 8 days longer than that in widest spacing $(75 \mathrm{~cm})$. Closer spacing resulted in a denser foliage, thus competing for sunlight and delaying flower induction.

Wider spacings of 50 and $75 \mathrm{~cm}$ produced significantly more basal branches per plant than did the closer spacings (table 1). This result is 
TABLE 1.-Effect of plant spacing on growth of winged bean

\begin{tabular}{|c|c|c|c|c|c|}
\hline \multicolumn{2}{|c|}{ Treatment } & \multirow{2}{*}{$\begin{array}{l}\text { Days to } \\
\text { first } \\
\text { flower }\end{array}$} & \multirow{2}{*}{$\begin{array}{c}\text { Number of } \\
\text { basal branch } \\
\text { per plant }\end{array}$} & \multirow{2}{*}{$\begin{array}{l}\text { Number of } \\
\text { green pod } \\
\text { per plant }\end{array}$} & \multirow[b]{2}{*}{$\begin{array}{c}\text { Green pod } \\
\text { weight }\end{array}$} \\
\hline $\begin{array}{l}\text { Within-row } \\
\text { spacing }\end{array}$ & $\begin{array}{c}\text { Plant } \\
\text { density }\end{array}$ & & & & \\
\hline $\mathrm{cm}$ & plantstha & & & & $g$ \\
\hline 75.0 & 13,333 & $63.0 \mathrm{a}^{1}$ & $3.8 \mathrm{a}$ & $83.3 \mathrm{a}$ & $29.0 \mathrm{a}$ \\
\hline 50.0 & 20,000 & $65.7 \mathrm{ab}$ & $3.6 \mathrm{a}$ & $65.3 \mathrm{~b}$ & $26.1 \mathrm{~b}$ \\
\hline 25.0 & 40,000 & $69.3 \mathrm{bc}$ & $2.9 \mathrm{~b}$ & $31.8 \mathrm{c}$ & $22.2 \mathrm{c}$ \\
\hline 12.5 & 80,000 & $71.0 \mathrm{c}$ & $2.4 \mathrm{~b}$ & $17.3 \mathrm{~d}$ & $21.1 \mathrm{~d}$ \\
\hline
\end{tabular}

${ }^{1}$ Mean separation in column by Duncan's multiple range test, $5 \%$ level.

similar to the findings about an Indonesian winged bean cultivar UGMl which produced 2.4 and 3.6 basal branches per plant at $1 \mathrm{~m} \mathrm{x} 12.5 \mathrm{~cm}$ and $1 \mathrm{~m} \times 75 \mathrm{~cm}$ spacings respectively. ${ }^{7}$

\section{Number of green pods}

Plant spacing significantly influenced the number of green pods per plant (table 1). The winged bean grown in widest plant spacing $(75 \mathrm{~cm})$ produced almost 5 times more green pods than that of closest spacing $(12.5 \mathrm{~cm})$. Competition for sunlight, moisture, and nutrients may have greatly restricted pod set at the closer plant spacings.

\section{Green pod weight}

Green pod weight of winged bean grown at closer plant spacings was significantly lighter than that at the wider spacings (table 1). Green pod weights at plant spacing $12.5,25,50$, and $75 \mathrm{~cm}$ were $21.1,22.2,26.1$ and $29 \mathrm{~g}$, respectively.

\section{Yields}

Table 2 shows the effect of plant spacing on yields of green pod and dry seed. Major factors affecting green pod yield are number of basal branches, number of green pods and green pod weight. Thus the fewer basal branches and pod numbers and smaller pod weight at the closer plant spacings $(12.5$ and $25 \mathrm{~cm})$ resulted in lower production of green pod (22.3 and $21.54 \mathrm{t} / \mathrm{ha}$, respectively) than wider spacings of 50 and $75 \mathrm{~cm}$ (26.12 and $24.80 \mathrm{t} / \mathrm{ha}$, respectively).

TABLE 2.-Effect of plant spacing on yield of winged bean

\begin{tabular}{cccc}
\hline \multicolumn{2}{c}{ Treatment } & Yield of \\
$\begin{array}{c}\text { Within-row } \\
\text { spacing }\end{array}$ & $\begin{array}{c}\text { Plant } \\
\text { density }\end{array}$ & $\begin{array}{c}\text { Yieen pod } \\
\text { green }\end{array}$ & $\begin{array}{c}\text { Yield of } \\
\text { dry seed }\end{array}$ \\
\hline $\mathrm{cm}$ & plants/ha & tha & kg/ha \\
75.0 & 13,333 & $24.80 \mathrm{a}^{1}$ & $6,468 \mathrm{a}$ \\
50.0 & 20,000 & $25.12 \mathrm{a}$ & $6,460 \mathrm{a}$ \\
25.0 & 40,000 & $21.54 \mathrm{~b}$ & $5,288 \mathrm{~b}$ \\
12.5 & 80,000 & $22.30 \mathrm{~b}$ & $5,138 \mathrm{~b}$ \\
\hline
\end{tabular}

${ }^{1}$ Mean separation in column by Duncan's multiple range test, $5 \%$ level. 
Dry seed yield with an average production of $6,460 \mathrm{~kg} / \mathrm{ha}$ at spacings of 50 and $75 \mathrm{~cm}$ was significantly higher than at spacings of 12.5 and 25 $\mathrm{cm}(5,138$ and $5,288 \mathrm{~kg} / \mathrm{ha}$, respectively). It was suggested that the lower seed yields at the closer spacings were presumably the result of competition for assimilation which induced seed abortion and restricted seed filling. ${ }^{8}$ For yields both of green pod and dry seed the optimum spacings were 50 and $75 \mathrm{~cm}$ within-row at $1 \mathrm{~m}$ between-rows. The result of higher yields indicated that cultivar Chimbu compensated for wider spacings by producing higher number of basal branches and green pods, and larger green pods than at closer spacings.

\section{RESUMEN}

Distancias de siembra, crecimiento y rendimento de la habichuela alada

El efecto de la densidad de siembra sobre la cosecha y las características agronómicas de la cultivar Chimbu de la habichuela alada se ha calculado en la Estación Agrícola de Guam. La distancia entre las plantas era de 12.5; $25 ; 50 ;$ y $75 \mathrm{~cm}$. Y la distancia entre hileras era de $1.22 \mathrm{~m}$. (equivalentes a 13,$333 ; 20,000 ; 40,000$ y 80,000 plantas por ha. Las plantas a menor distancia $(12.5 \mathrm{~cm}$.) florecieron 8 días más tarde que las más apartadas $(75.0 \mathrm{~cm}$.). Las más apartadas $(50$ y $75 \mathrm{~cm}$ ) ) tenían más ramas florales $(3.6$ y 3.8, respectivamente) y más vainas verdes por planta $(65.3$ y 83.3 , respectivamente) que las sembradas a 12.5 y $25 \mathrm{~cm}$. Las mejor cosecha de vainas verdes y semillas secas se obtuvo a 50 y $75 \mathrm{~cm}$. La producción más elevada de la habichuela alada cultivar Chimbu se logró en las plantas más espaciadas porque tenían un mayor número tanto de ramas florales como de vainas más grandes.

sStephenson, R. A., 1978. Field Studies on winged beans growth and yield. Paper presented in the 1st International Symposium on Developing the Potentials of the Winged Bean, Manila, Philippines, 191-96. 